\title{
Editorial: Foodways as Intangible Cultural Heritage
}

\author{
Chiara Bortolotto*
}

\section{Benedetta Ubertazzi†}

"When I read the definition of Intangible Cultural Heritage I thought, this was written for French gastronomy!” These were the words used by the director of the European Institute for the History and Cultures of Food, the main promoter of what would later be called the "Gastronomic meal of the French," to enthusiastically explain the idea of preparing a nomination to the Representative List of the Intangible Cultural Heritage of Humanity during the first "Meeting of Experts," charged with "defining the intellectual and scientific content of the file." 1 This reaction also more generally reflects how foodways are perceived by social actors as part and parcel of what, following the language introduced by the United Nations, we globally call intangible cultural heritage (ICH).

The role played by food and foodways as identity markers is highlighted, for instance, in historical and anthropological accounts of Italian immigration overseas between the end of the nineteenth and the beginning of the twentieth centuries, ${ }^{2}$ where the notion of "local specialty" (prodotto tipico) and the narrative of regional cuisine as a barrier against assimilation contributed to the establishment of "culinary

\footnotetext{
${ }^{\star}$ Research Associate, Institut interdisciplinaire d'anthropologie du contemporain; Principal Investigator of UNESCO Frictions: Heritage-Making across Global Governance, School of Advanced Studies in the Social Sciences, Paris, France; Email: chiara.bortolotto@ehess.fr.

${ }^{\dagger}$ Aggregate Professor, School of Law, University of Milan-Bicocca; practicing attorney in Intellectual property and business law, Studio Ubertazzi, Milan, Italy; Contracted Professor of International Intellectual Property Law and UNESCO Intangible Cultural Heritage Law, School of Law, Federal State Budgetary Educational Institute of Higher Education "Saint-Petersburg State University"; UNESCO facilitator, Global Capacity-Building Programme for the Effective Implementation of the 2003 Convention on Safeguarding Intangible Cultural Heritage; Email: benedetta.ubertazzi@ubertazzi.it.

${ }^{1}$ Letter to Chiara Bortolotto from Francis Francis Chevrier, director of the European Institute for the History and Cultures of Food, 16 February 2007 (on file with the author).

${ }^{2}$ Magliocco 1993.
} 
homelands." ${ }^{3}$ Spurred by encounters with new culinary habits and systems, a similar form of nostalgia for bygone culinary worlds ${ }^{4}$ is today coupled with the perception of a loss of cultural and biological diversity and has triggered a reconceptualization of food and foodways as heritage to be cherished and protected. ${ }^{5}$

The food heritage phenomenon has been explained as a "contemporary attempt at re-identification" against the backdrop of a search for identity in a world regarded as increasingly homogenous. ${ }^{6}$ The neologism "McDonaldization," commonly used as a pejorative synonym of globalization, demonstrates that the standardization of food practices is, in fact, representative of a wider phenomenon. " "Identity foods" have been created as a reaction against this reality through several apparatuses: intellectual property rights (IPRs), such as geographical indications (GIs) and protective denomination of origin, have enshrined such products within circumscribed geographical zones; regulations have normalized so-called traditional production processes; and festivals and other local events have promoted local economies. ${ }^{8}$ Rooted in historical and geographical claims, a narrative of authenticity is used to portray culinary cultures and skills (as opposed to standardized practices based on mass-produced foodstuffs) and functions as a strategy for creating a niche market for quality food. In creating and proving food "localness," inscription on the UNESCO lists is regarded by heritage actors as a key tool for the protection and promotion of culinary cultures and is, in this sense, very much part and parcel of globalization and global consumption. ${ }^{9}$

This special issue of the International Journal of Cultural Property gathers seven articles that explore, from different disciplinary perspectives, the rise of food heritage within the policy field established by the UNESCO Convention for the Safeguarding of the Intangible Cultural Heritage $(\mathrm{CSICH}) .{ }^{10}$ From its very introduction in early 2000, the concept of ICH has, in fact, been associated with the food realm, if in a controversial manner. For example, even before the CSICH entered into force, the Italian National Commission for UNESCO received requests for nominating "balsamic vinegar" and "pizza." The government did not end up pursuing these requests, but the international press reacted to the potential nomination of pizza with irony and puzzlement. ${ }^{11}$ Yet, as both Julia Csergo and Harriet Deacon show in their articles in this issue, the inscriptions, all in 2010, of the "gastronomic

\footnotetext{
${ }^{3}$ Teti 1999.

${ }^{4}$ Mannur 2007; Abbots 2016.

${ }^{5}$ Brulotte and Di Giovine 2014.

${ }^{6}$ Geyzen 2016, 68.

${ }^{7}$ Ritzer 1993; Fischler 1996.

${ }^{8}$ Poulain 1997; Delfosse and Letablier 1999; Chevallier 2004.

${ }^{9}$ Sammells 2014.

${ }^{10}$ Convention for the Safeguarding of Intangible Cultural Heritage, 17 October 2003. Some of these articles were presented at a session at the 2016 Association of Critical Heritage Studies conference, held in Montreal, Canada.

${ }^{11}$ Bortolotto 2017.
} 
meal of the French," "traditional Mexican cuisine," and "Mediterranean diet" have paved the way for an increasing number of food-related nominations, including, more than 15 years after the first attempt, that of pizza under the title "art of Neapolitan pizzaiuolo" in 2017. The food-ICH fever continues to grow; national and local press worldwide report numerous attempts to have foodways recognized by UNESCO. Even if most do not make it to even the respective national inventories, such efforts reflect the enthusiasm for food-related ICH. Examples range from Belgian fries to the French baguette, from Confucian family cuisine ${ }^{12}$ to Spanish tapas, from German bread ${ }^{13}$ to Swiss raclette.

However, according to one of the founding fathers of the $\mathrm{CSICH}, \mathrm{ICH}$ was never supposed to have been about food or cuisine. Indeed, foodways are not represented among the five domains exemplifying the definition of ICH. When debate over food-related elements first arose within UNESCO, an expert meeting was organized in France to discuss the issue. ${ }^{14}$ The experts highlighted the need to give a pivotal role to cultural and social processes associated with foodways without referring to the products themselves. The reasoning was that this would allow for a representation of foodways as ritual, cultural, and social expressions of a community, thus contextualizing the latter in what was regarded as the field of intervention of the $\mathrm{CSICH}$ in a way that was consistent with its original spirit.

In a clear example of what Peter Larsen defines as "guidance culture," 15 these expert recommendations heavily influenced the way that the French gastronomy nomination was drafted. ${ }^{16}$ As Voltaire Cang demonstrates in this volume, the expert guidance also had a much broader influence, as the French file was subsequently used as a model for the Japanese nomination of "washoku, traditional dietary cultures of the Japanese, notably for the celebration of New Year" and has been credited as one of the reasons for its positive evaluation. Indeed, a lack of alignment with this way of representing culinary heritage is regarded as one of the main reasons behind the general absence of Chinese cuisine on the lists. ${ }^{17}$

However, as both Cang and Antonio da Silva illustrate in their respective articles, carefully drafted nomination files that follow the recommendations of this expert meeting, and are accordingly devoid of references to products, reflect more of a rhetorical strategy than the actual priorities of the promoters of the inscription of these food-related elements on the list. For example, the Japanese project was

\footnotetext{
12Demgeski (forthcoming).

${ }^{13}$ Bendix 2014.

${ }^{14}$ Expert Meeting on Culinary Practices, Vitré, France, 4-5 April 2009.

${ }^{15}$ Larsen 2013.

${ }^{16}$ Bortolotto 2017.

${ }^{17}$ Demgeski (forthcoming).
} 
in part triggered by "gastronationalism" 18 and competition with their Korean neighbors and in part by the wish to support food producers brought to their knees after the Fukushima nuclear disaster. Indeed, "certification schemes" to promote the economic interests of Japan's food producers and to "authenticate" washoku chefs were created after the inscription. Similarly, the inscription of the "Mediterranean diet" mainly, but not explicitly, aimed to promote an "umbrella brand" of agro-food products individually protected by GIs. Csergo's analysis of the nomination files of food-related inscriptions on the UNESCO lists shows that economic objectives have been increasingly prioritized in the way safeguarding measures are conceived. In such cases, in order to recognize who benefits from the promotion of ICH elements, it becomes crucial to know who owns them.

Such initiatives have also sparked heated debate within UNESCO, where there is palpable distress over the increasing obligation to deal with gastro-diplomacy ${ }^{19}$ and where diplomats and experts continue to make a fuss about food-related nominations. A shared opinion circulating the UNESCO corridors is that ICH lists should not turn into a menu of world cuisine and that this trend should be stopped or at least slowed. Indeed, culinary nostalgia is clearly not the only trigger in the booming market of food heritage; this category goes hand in hand with a broader, and much more controversial, shift linking ICH to the market in an unprecedented way.

Such concerns are particularly relevant as commodification is regarded as a major risk of ICH promotion. Yet the market often intersects with, and is necessary for, the perpetuation of food-related cultural practices. For example, based on his analysis of the "traditional agricultural practice of cultivating the 'vite ad alberello' (head-trained bush vines) of the community of Pantelleria," the "beer culture in Belgium," and "yoga," Tomer Broude's contribution shows the "ambivalence of ICH safeguarding, broadly understood well beyond static preservation, and ultimately dependent on commodification or at least significantly prone to commercial capture." Along similar lines, da Silva and Csergo, looking at the "Mediterranean diet" and the "gastronomic meal of the French," and Raúl Matta on the failed nomination of Peruvian cuisine, ${ }^{20}$ all highlight the role of major agro-business brands and interest groups in the promotion of food-related ICH. In shedding light on the social, political, and economic uses of heritage against the backdrop of global policy developments, the controversial nature of food-related nominations to the UNESCO ICH lists provides a catalyst for broader reflection on the political economy of cultural transmission.

\footnotetext{
$\overline{{ }^{18} \text { DeSoucey } 2010 .}$

${ }^{19}$ Rockower 2012.

${ }^{20}$ Matta 2016.
} 
Legal and marketing measures associated with food-related $\mathrm{ICH}$ are important tools in this political economy, used by ICH communities to safeguard their heritage. Such tools fall under the concepts of "protective" and "promotion" safeguarding measures according to Article 2.3 of the CSICH. These same tools also highlight to consumers what communities think is the added value/attributes of their ICH. Namely, these tools attribute the ICH cultural environment or origin, of both human and territorial nature, to a specific quality, reputation, and other characteristic. ${ }^{21}$ Such measures include IPRs, such as GIs, and collective and certification trademarks. IPRs are constituted by "signs" and regulations (in the case of collective trademarks) and by specifications (in relation to GIs) and are typically grounded on traditional production processes-namely, of a food or foodway nature. ${ }^{22}$ At the same time, marketing instruments are adopted in relation to these same elements, based on similar strategies, aimed at emphasizing the attributes of ICH to consumers.

IPRs and marketing measures and strategies for $\mathrm{ICH}$ are therefore strictly linked. ${ }^{23}$ Moreover, they concern not only food and foodways but also all of the different domains of intangible heritage indicated by Article 2.2 of the CSICH. Among the various ICH elements inscribed in the UNESCO lists that mention adopting IPRs as safeguarded measures in their respective nomination files are "Dikopelo folk music of Bakgatla ba Kgafela in Kgatleng District" (Botswana), ${ }^{24}$ "Sega tambour of Rodrigues Island" (Republic of Mauritius)," 25 and "Međimurska popevka, a folksong from Međimurje" (Croatia), ${ }^{26}$ which all adopt copyright; "Indonesian batik" (Indonesia), ${ }^{27}$ which registers a certification trademark; "traditional violin craftsmanship in Cremona" (Italy), ${ }^{28}$ which utilizes a collective trademark; "weaving of Mosi (fine ramie) in the Hansan region" (South Korea), ${ }^{29}$

\footnotetext{
${ }^{21}$ Rinallo 2018.

${ }^{22}$ Ubertazzi 2017; Deacon and Smeets 2018; Lixinski 2018; Ubertazzi (forthcoming).

${ }^{23}$ Deacon et al. 2019.

24“Dikopelo folk music of Bakgatla ba Kgafela in Kgatleng District," Nomination file no. 01290, Doc. 12.COM, 2017, https://ich.unesco.org/en/USL/dikopelo-folk-music-of-bakgatla-ba-kgafelain-kgatleng-district-01290 (accessed 7 February 2019).

25"Sega tambour of Rodrigues Island," Nomination file no. 01257, Doc. 12.COM, 2017, https://ich. unesco.org/en/RL/sega-tambour-of-rodrigues-island-01257 (accessed 7 February 2019).

26"Međimurska popevka, a folksong from Međimurje," Nomination file no. 01396, Doc. 13.COM, 2018, https://ich.unesco.org/en/RL/meimurska-popevka-a-folksong-from-meimurje-01396 (accessed 15 February 2017).

27“"Indonesian batik," Nomination file no. 00170, Doc. 4.COM, 2009, https://ich.unesco.org/en/RL/ indonesian-batik-00170 (accessed 7 February 2019).

${ }^{28 “}$ "Traditional violin craftsmanship in Cremona," Nomination file no. 00719, Doc. 7.COM, 2012, https://ich.unesco.org/en/RL/traditional-violin-craftsmanship-in-cremona-00719 (accessed 7 February 2019).

29“"Weaving of Mosi (fine ramie) in the Hansan region," Nomination file no 00453, Doc. 6.COM, 2011, https://ich.unesco.org/en/RL/weaving-of-mosi-fine-ramie-in-the-hansan-region-00453 (accessed 18 February 2019).
} 
"traditional craftsmanship of Çini-making" (Turkey), 30 "know-how of cultivating mastic on the island of Chios" (Greece), ${ }^{31}$ and "Argan, practices and know-how concerning the argan tree" (Morocco), ${ }^{32}$ which have all registered GIs. ${ }^{33}$

Issues of intellectual property and marketing measures and strategies are particulaly interesting for food-related elements. The great majority of international treaties on GIs concern food and foodways, such as the 1951 Stresa Convention on the Protection of Appellations of Origin and Names of Cheese; ${ }^{34}$ the 1958 Lisbon Agreement on the Protection of Appellation of Origin; ${ }^{35}$ the bilateral and multilateral agreements on GIs related to wine and spirits; 36 those concluded by the European Union (EU) with Switzerland in $2011^{37}$ and with Georgia in 2012; ${ }^{38}$ others that include GIs in economic partnership agreements, ${ }^{39}$ in the Stabilisation and Association Agreement, ${ }^{40}$ and in free trade agreements; ${ }^{41}$ and, finally, the Geneva Act

30“Traditional craftsmanship of Çini-making," Nomination file no. 01058, Doc. 11.COM, 2016, https:// ich.unesco.org/en/RL/traditional-craftsmanship-of-cini-making-01058 (accessed 18 February 2019).

31 "Know-how of cultivating mastic on the island of Chios," Nomination file no. 00993, Doc. 9.COM, 2014, https://ich.unesco.org/en/RL/know-how-of-cultivating-mastic-on-the-island-of-chios-00993 (accessed 18 February 2019).

32"Argan, practices and know-how concerning the argan tree," Nomination file no. 00955, Doc. 9.COM, 2014, https://ich.unesco.org/en/RL/argan-practices-and-know-how-concerning-the-argantree-00955 (accessed 18 February 2019).

${ }^{33}$ Ubertazzi 2017.

${ }^{34}$ See the International Convention on the Use of Appellations of Origin and Denominations of Cheeses, 1 June 1951, https://www.admin.ch/opc/fr/classified-compilation/19510137/index.html (accessed 18 February 2019).

${ }^{35}$ See the Lisbon Agreement for the Protection of Appellations of Origin and their International Registration, 31 October 1958, http://www.wipo.int/lisbon/en/legal_texts/lisbon_agreement.html (accessed 18 February 2019).

${ }^{36}$ See bilateral wine agreements between the European Union (EU) and third countries, notably with Mexico (1997), South Africa (1999), Chile (2002), Canada (2003), the United States (2006), and Australia (2009).

${ }^{37}$ See the EU-Switzerland Agreement on the Protection of Designations of Origin and Geographical Indications for Agricultural Products and Foodstuffs, 19 January 2011, [2011] OJ L297.

${ }^{38}$ See the Agreement between the European Union and Georgia on Protection of Geographical Indications of Agricultural Products and Foodstuffs, 14 July 2011, [2011] OJ L93.

${ }^{39}$ See the Economic Partnership Agreement between the CARIFORUM States, on the One Part, and the European Community and Its Member States, on the Other Part, 15 October 2008, [2008] OJ L289 https://www.eda.admin.ch/countries/china/de/home/vertretungen/botschaft/aufgaben/wirtschaftfinanzen/china-switzerland-free-trade-agreement.html.

${ }^{40}$ See the Stabilisation and Association Agreement between the European Communities and Their Member States, on the One Part, and the Republic of Albania, on the Other Part, 12 June 2006, [2006] OJ L107; Stabilisation and Association Agreement between the European Communities and Their Members States, on the One Part, and the Republic of Serbia, on the Other Part, 29 April 2008, [2008] OJ L278; EU-Bosnia Herzegovina Stabilisation and Association Agreement, 16 June 2008, [2008] OJ L164.

${ }^{41}$ See the Free Trade Agreement between the European Union and Its Member States, on the One Part, and the Republic of Korea, on the Other Part, 6 October 2010, [2010] OJ L127; Free Trade Agreement between the Swiss Confederation and the People's Republic of China, 6 July 2013. 
of the Lisbon Agreement concluded in 2015. ${ }^{42}$ Similarly, EU Regulation 1151/2012 on Quality Schemes for Agricultural Products and Foodstuffs renders GIs available for agricultural products and foodstuffs. ${ }^{43}$

Against the backdrop of rising heritage entrepreneurship and increasing associated claims of IPRs, ${ }^{44}$ food-related ICH has become a clear example of how culture is increasingly conceptualized as a resource that can foster "sustainable" economic development. ${ }^{45}$ Assertions of ownership of such resources become crucial to the communities concerned, where there is a widespread belief that such claims will better protect and promote their ICH and, in turn, act as a better safeguard, allowing them to benefit from any economic advantages. This is well highlighted in Gyooho Lee's analysis of the kimchi case in this issue, wherein he writes that this long-standing traditional staple food could be registered as a trademark, which would prevent foreign governments, legal entities, and individuals from obtaining a similar trademark. According to Lee, traditional food and foodways can be protected in Korea pursuant to patent law, unfair competition law, and similar systems, although they are a particularly good subject matter for GI protection. In addition, defensive protection of similar traditions has been achieved in Korea through national Internet portals, which contain information on traditional foodways. These portals prevent non-community members (individuals, legal entities, and foreign governments) from patenting Korean traditional food and recipes due to the lack of novelty.

IPR registration and $\mathrm{ICH}$ inscription are sometimes perceived as specific and complementary measures for safeguarding foodways. Yet the adoption of IPRs (and marketing strategies) by communities on their ICH can create tensions. For example, the communities that are indicated as the IPR owners in the relevant GI specification or trademark regulation may not correspond to those identified as the ICH bearers in the corresponding UNESCO nomination files. Such frictions, however, can be reduced by adopting IPRs that specify the relevant community in a flexible way, including, for instance, all possible producers who use the traditional recipe, wherever they may be located. This is the case for the traditional specialty guaranteed (TSG) food designation (which is an IPR closed to GI) registered for "Pizza Neapolitan." In this issue, Deacon analyses the registration of this TSG and the inscription on the UNESCO Representative List of the Intangible Cultural Heritage of Humanity of "the art of Neapolitan pizzaiuolo." She concludes that

\footnotetext{
${ }^{42}$ See the Geneva Act of the Lisbon Agreement on Appellations of Origin and Geographical Indications, 20 May 2015.

${ }^{43}$ Council Regulation 1151/2012 on quality schemes for agricultural products and foodstuffs, [2012] OJ L343. See, however, Council Resolution 2015/2053 on the possible extension of geographical indication protection of the European Union to non-agricultural products, http://www.europarl.europa. eu/sides/getDoc.do?pubRef=-//EP//NONSGML+TA+P8-TA-2015-0331+0+DOC+PDF+V0//EN (accessed 7 February 2019).

${ }^{44}$ Pfeilstetter 2015.

${ }^{45}$ Yúdice 2004.
} 
this parallel IPR registration / ICH nomination could favor communities in that it provides IPR protection while also bolstering the prestige of their "traditional" food. Moreover, this could enable producers to compete more effectively against the market for frozen and factory-made pizzas and thereby encourage the future practice and transmission of the traditional art of making pizzas by hand. However, as Deacon highlights, possible conflict could arise between the TSG specification and the ICH nomination form with regard to both the naming and nature of toppings and the identification of the community as the IPR owner versus the ICH bearer. Yet distinguishing the communities concerned is a common problem inherent in both ICH and TSG systems. Deacon argues that such issues can only be resolved by paying careful attention to the drafting of traditional recipes and the identification of the relevant communities in both the TSG specifications and the ICH nominations.

Finally, intellectual property is not the only salient aspect in complex interactions between the cultural dimensions of food and foodways and international law regimes. Lucas Lixinski and Broude, for example, respectively highlight the roles of the international environment, transport, human rights, and trade law. ${ }^{46}$ Lixinski concludes that "food as ICH remains largely an isolated and fairly discrete way of thinking about food as an object of international legal attention, and it misses a fairly complex web of interrelationships." ${ }^{47}$ In relation to trade law regimes, Broude observes that "an ICH inscription may serve the purposes of factual determination and interpretation under WTO law, ... demonstrating that the $[\mathrm{CSICH}]$ may indeed translate into concrete effects in international trade law." 48

The articles collected in this issue demonstrate the ways that food-related heritage has become the object of diverse kinds of protection, promotion, and safeguarding based on a combination of different instruments. This combination establishes complex heritage regimes where social actors endeavor, in more or less consistent ways, to represent and use their heritage and, in doing so, to articulate narratives of cultural diversity and sustainable development against the backdrop of a neoliberal economy.

\section{BIBLIOGRAPHY}

Abbots, Emma-Jayne. 2016. "Approaches to Food and Migration: Rootedness, Being, and Belonging." In The Handbook of Food and Anthropology, edited by J. Klein and J. Watson, 115-32. London: Bloomsbury.

\footnotetext{
${ }^{46}$ See also the interdisciplinary approach for assessing the emerging concept of agro-biodiversity and its relationship with food security, nutrition, health, environmental sustainability, and climate change, which was adopted by Santilli 2012.

${ }^{47}$ Lixinski, "Food as Heritage and Multi-Level International Legal Governance," in this issue.

${ }^{48}$ Broude, "Mapping the Potential Interactions between UNESCO's Intangible Cultural Heritage Regime and World Trade Law," in this issue.
} 
Bendix, Regina. 2014. "Daily Bread, Global Distinction? The German Bakers' Craft and Cultural ValueEnhancement Regimes." In Brulotte and Di Giovine, Edible Identities: Food as Cultural Heritage, 185-200.

Bortolotto, Chiara. 2017. "Como 'comerse' un patrimonio: construer bienes inmateriales agroalimentarios entre directivas tecnicas y empresariado patrimonial." Revista Andaluza de Antropologia 12: 144-66.

Brulotte, Ronda L., and Michael A. Di Giovine, eds. 2014. Edible Identities: Food as Cultural Heritage. Surrey: Ashgate.

Chevallier, Denis. 2004. "Produits, pays, paysages entre relance et 'labellisation'." In Fabrication des traditions. Invention de modernité, edited by D. Dimitrijevic, 275-86. Paris: Éditions de la Maison des sciences de l'homme.

Deacon, Harriet, and Smeets Rieks. 2018. "Intangible Heritage Safeguarding and Intellectual Property Protection in the Context of Implementing the UNESCO ICH Convention." In Safeguarding Intangible Heritage: Practices and Politics, edited by N. Akagawa and L. Smith, 36-53. London: Routledge.

Deacon, Harriet, Charlotte Waelde, Diego Rinallo, Ananya Bhattacharya, and Benedetta Ubertazzi. 2019. "Interdisciplinary Approaches to Understanding the Question of Commercialization in Intangible Heritage Safeguarding under the 2003 UNESCO Convention.” Abstract submitted to the workshop Intangible Cultural Heritage: Reconceptualization, Uses, Marketization, Zhejiang University, 17-18 May 2019.

Delfosse, Claire, and Marie-Thérèse Letablier. 1999. "Comment renaissent les fromages? L'époisses, le rocroi, le soumaintrain." In Carrières d'objets: Innovations et relances, edited by Ch.Bromberger and D. Chevallier, 161-80. Paris: Éditions de la Maison des sciences de l'homme.

Demgenski, Philipp. Forthcoming. "Culinary Tensions: Chinese Cuisine's Rocky Road towards Intangible Cultural Heritage." In Asian Ethnology.

DeSoucey, Michaela. 2010. "Gastronationalism: Food Traditions and Authenticity Politics in the European Union.” American Journal of Sociology 75: 432-55.

Fischler, Claude. 1996. "La 'macdonaldisation' des mœurs." In Histoire de l'alimentation, edited by J. L. Flandrin and M. Montanari, 874-75. Paris: Fayard.

Geyzen, Anneke. 2014. "Food Studies and the Heritage Turn: A Conceptual Repertoire." Food and History 12, no. 2: 67-96.

Larsen, Peter Bille. 2013. "The Politics of Technicality: Guidance Culture in Environmental Governance." In The Gloss of Harmony: The Politics of Policy-Making in Multilateral Organization, edited by B. Müller, 75-100. London: Pluto.

Lixinski, Lucas. 2018. "Intangible Heritage Economics and the Law: Listing, Commodification and Market Alienation." In Safeguarding Intangible Heritage: Practices and Politics, edited by N. Akagawa and L. Smith, 54-67. London: Routledge.

Magliocco, Sabrina. 1993. "Paying with Food." In Studies in Italian-American Folkore, edited by L. Del Giudice, 107-26. Logan: Utah State University Press.

Mannur, Anita. 2007. "Culinary Nostalgia: Authenticity, Nationalism, and Diaspora." MELUS 32, no. 4: 11-31.

Matta, Raúl. 2016. "Food Incursions into Global Heritage: Peruvian Cuisine's Slippery Road to UNESCO.” Social Anthropology 24, no. 3: 338-52. 
Pfeilstetter, Richard. 2015. "Heritage Entrepreneurship: Agency-driven Promotion of the Mediterranean Diet in Spain. International Journal of Heritage Studies 21, no. 3: 215-31.

Poulain, Jean Pierre. 1997. “Goût du terroir et tourisme vert à l'heure de l'Europe.” Etnologie Française 17, no. 1: 18-26.

Rinallo, Diego. 2018. "Map of ICH Food Commercial Valorisation Practices across the Alpine Space: Deliverable D.T.2.1.1.” https://www.alpinespace.eu/projects/alpfoodway/project-results/ wp2_map_ich_commercial_valorisation_practices.pdf (accessed 19 February 2019).

Ritzer, George. 1993. The McDonaldization of Society. Thousand Oaks, CA: Pine Forge Press.

Rockower, Paul S. 2012. "Recipes for Gastrodiplomacy." Place Branding and Public Diplomacy 8: 235-46.

Sammells, Clare. 2014. "Haute Traditional Cuisines: How UNESCO’s List of Intangible Heritage Links the Cosmopolitan to the Local." In Edible Identities: Food As Cultural Heritage, edited by R. Brulotte and M. Di Giovine, 141-58. Surrey: Ashgate.

Santilli, Juliana. 2012. Agrobiodiversity and the Law: Regulating Genetic Resources, Food Security and Cultural Diversity. New York: Earthscan.

Teti, Vito. 1999. Il colore del cibo. Rome: Meltemi.

Ubertazzi, Benedetta. 2017. "EU Geographical Indications and Intangible Cultural Heritage." International Review of Intellectual Property and Competition Law 48, no. 5: 562-87.

Ubertazzi, Benedetta. Forthcoming. "Italian Intangible Cultural Heritage Inscribed on the ICH UNESCO List: Risks and Opportunities. In The Legal Protection of Intangible Cultural Heritage, edited by P. L. Petrillo. Zurich, Switzerland: Springer Nature.

Yúdice, George. 2004. The Expediency of Culture: Uses of Culture in the Global Era. Durham, NC: Duke University Press. 